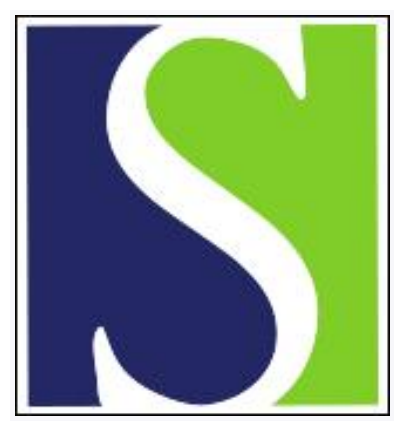

Scand J Work Environ Health 1999;25(4):309-316

https://doi.org/10.5271/sjweh.440

Issue date: Aug 1999

Risk of developing lung cancer in relation to exposure to fumes from Chinese-style cooking

by Zhong L, Goldberg MS, Parent M-É, Hanley JA

Key terms: environment; indoor air pollution; lung neoplasms; review

This article in PubMed: www.ncbi.nlm.nih.gov/pubmed/10505656

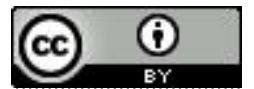




\title{
Risk of developing lung cancer in relation to exposure to fumes from Chinese-style cooking
}

\author{
by Lijie Zhong, MD, ${ }^{1,2}$ Mark S Goldberg, PhD, ${ }^{1,3}$ Marie-Élise Parent, PhD, ${ }^{3}$ James A Hanley, PhD'
}

\begin{abstract}
Zhong L, Goldberg MS, Parent M-É, Hanley JA. Risk of developing lung cancer in relation to exposure to fumes from Chinese-style cooking. Scand J Work Environ Health 1998;25(4):309-316.

In an evaluation of the association between exposure to indoor air pollution from Chinese-style cooking and the risk of lung cancer, epidemiologic and experimental studies were reviewed. The 9 case-referent studies that were identified showed consistent positive associations between the risk of lung cancer and a variety of indices of exposure to indoor air pollution arising from Chinese-style cooking. Three experimental studies showed that volatile emissions from oils heated in woks are mutagenic in several in vitro short-term test systems. Several toxic agents, including some accepted or suspected carcinogens, have been detected in the emissions of the heated cooking oils. While experimental data support the epidemiologic data, it may be premature to conclude that the association is causal. However, simple precautions can be taken to reduce the risk in the event that exposure to indoor air pollution arising from Chinese-style cooking is indeed a cause of lung cancer.
\end{abstract}

Key terms environment, indoor air pollution, lung neoplasms, review.

The incidence of lung cancer among women living in China is among the highest in the world (about 20 per 100000 persons per year) $(1,2)$. High rates have also been found among Chinese women living in Singapore (3), Hong Kong (4, 5), Taiwan (6), the United States (79), Australia (10), and Malaysia (11). Tobacco smoking does not appear to be a major risk factor for lung cancer in Chinese women because few Chinese women smoke cigarettes (12) and those who smoke do not consume as much as others (13-15). As a consequence, for Chinese women, the etiologic fraction for tobacco smoking (about $24 \%$ ) is much lower than for other populations (16). However, other environmental exposures, such as occupational carcinogens (17), outdoor air pollution (15), exposure to environmental tobacco smoke $(5,6,13,18)$, and indoor air pollution from Chinese-style cooking (5, $6,13-15,18-21$ ), may cause lung cancer in Chinese women. This review summarizes the published data regarding the risk of lung cancer from indoor air pollution arising from Chinese-style cooking. It covers both epidemiologic data and available data regarding the genotoxicity of condensates of volatile emissions from heated cooking oils.

\section{Organic compounds generated from heated cooking oils}

The identification of organic compounds in fumes of heated cooking oils typically involves heating the oil in a covered wok to sufficiently high temperatures so that fumes are produced (rapeseed oils $275-280^{\circ} \mathrm{C}$, soybean oils $260-265^{\circ} \mathrm{C}$ ), recovering the fumes on filters attached to the cover, and then using acetone to extract the condensates from the filters (22-24). Gas chromatographic and mass spectrometric analyses are used to identify the individual chemical components of the condensates. About 54 compounds have been identified in the fumes of heated Chinese rapeseed, soybean, peanut oil, and refined North American rapeseed oil (known as canola oil) $(23,24)$. See the appendix for a list. Most of the compounds listed in the appendix have been found to be present in all 4 oils, but the concentrations of certain volatile organic compounds differed considerably between the oils. In particular, concentrations of 1,3 butadiene and benzene were approximately 22 -fold and 12 -fold higher, respectively, in heated Chinese rapeseed oil than in heated Chinese peanut oil. Heating the oil to lower

1 Joint Departments of Epidemiology, Biostatistics and Occupational Health, McGill University, Montreal, Quebec, Canada.

2 Department of Epidemiology, Shanghai Cancer Institute, Shanghai, People's Republic of China.

3 Epidemiology and Biostatistics Unit, INRS-Institut Armand-Frappier, University of Quebec, Laval, Quebec, Canada.

Reprint requests to: Dr Mark S Goldberg, Epidemiology and Biostatistics Unit, INRS-Institut Armand-Frappier, University of Quebec, 531, Boulevard des Prairies, Laval, QC, Canada H7V 1B7. [E-mail: mark@polair.epi.mcgill.ca] 
temperatures results in the production of fewer volatile organic compounds (23). Among the chemicals detected, 1,3-butadiene, acetaldehyde, and formaldehyde have been classified as probable human carcinogens (25), benzene is an accepted human carcinogen (25), and acrolein is mutagenic (26).

\section{Genotoxicity of condensates of heated oils}

The genotoxicity of emissions from heated oils has been tested in a variety of in vitro short-term systems. Mutagenicity has been assessed using the Ames test (tester strain TA98 activated by $S 9$ homogenates) $(22,23)$, and it was found that condensates from heated unrefined rapeseed oil, heated refined rapeseed oil, and heated soybean oil were mutagenic. In addition, the mutagenic activity (measured by the number of revertants) of heated unrefined rapeseed oil condensates increased with increasing temperature. In comparison, the condensates from heated peanut oil, sesame oil, lard, canola oil, and unheated oils were not mutagenic. It was also found that linolenic acid, which is present in rapeseed oils, was mutagenic and that the mutagenic activity of volatile emission condensates was correlated with the concentration of linolenic acid (Pearson correlation coefficient 0.83). In addition, $\mathrm{Qu}$ et al (22) also found that condensates from unrefined rapeseed oil were genotoxic in the SV50 forward mutation assay, in the sister-chromatid exchange assay, and in the micronuclei assay.

\section{Epidemiologic studies}

Epidemiologic studies of lung cancer and exposure to indoor air pollution from Chinese-style cooking were sought using citations indexed between 1975 and 1998 in the MEDLINE bibliographic data base, supplemented by references quoted in the recovered articles. Excluded were articles in languages other than English or Chinese. Eight case-referent studies were found $(3,6,13-15$, $18-20)$ from the search. We also added a study that we completed recently (21), 9 studies therefore being included in this review.

\section{Design characteristics}

Details of the design and results of the studies are presented in table 1 . The study by Wu-Williams et al (14) and the study by $\mathrm{Xu}$ et al (15) were based on the same group of subjects, and results for men were presented only in the latter paper. Five studies were restricted to women $(6,14,18,20,21)$, and 2 studies included nonsmoking women $(6,21)$. In 6 studies, referents were selected from the general population $(14,15,18,19,21)$ or from the neighborhood where the cases lived (20), and for the other 3 studies referents were selected from hospital patients $(3,6,13)$. Response rates in 7 studies $(6$, $13-15,18,19,21)$ were above $87 \%$, and in the remaining 2 studies the response rates were not specified $(3,20)$. Our personal experience with conducting studies in China suggests that these 2 studies were also likely to have had high response rates. In the 7 studies reporting response rates, the differences in response between case

Table 1. Summary of case-referent studies of lung cancer and indoor air pollution from Chinese-style cooking.

\begin{tabular}{|c|c|c|c|c|}
\hline Study period & Study population & Comparison & Odds ratio ( $95 \%$ confidence interval) & Comments \\
\hline $\begin{array}{l}\text { 1972-1973: } \\
\text { MacLennan et } \\
\text { al, } 1977(3)\end{array}$ & $\begin{array}{l}147 \text { male and } 86 \text { female } \\
\text { case subjects; } 134 \text { male } \\
\text { and } 166 \text { female hospital } \\
\text { patients in Singapore; } \\
\text { patients with smoking- } \\
\text { related diagnoses } \\
\text { excluded from the } \\
\text { reference group }\end{array}$ & Subjects ever cooked versus never & $\begin{array}{l}\text { Men: } 1.6(0.7-3.2)^{\mathrm{a}} \\
\text { Cantonese women: } 1.7(0.7-4.5)^{\mathrm{a}} \text {, } \\
\text { non-Cantonese women: } 0.4(0.2-0.9)^{\mathrm{a}}\end{array}$ & $\begin{array}{l}\text { No control of potential } \\
\text { confounding factors; } \\
\text { exposure index not } \\
\text { well defined; response } \\
\text { rates and percentage } \\
\text { of cases histologically } \\
\text { confirmed not reported }\end{array}$ \\
\hline $\begin{array}{l}1992-1993 ; \\
\text { Ko et al, } 1997 \\
\text { (6) }\end{array}$ & $\begin{array}{l}\text { Nonsmokers in } \\
\text { Taiwan: } 117 \text { women } \\
\text { with lung cancer; } 117 \\
\text { women mached for age } \\
\text { and gender, selected } \\
\text { from ophthalmic } \\
\text { patients and general } \\
\text { physical examination, } \\
\text { nonresponse rate } 9 \% \\
\text { for case subjects and } \\
6 \% \text { for referents }\end{array}$ & $\begin{array}{l}\text { Age when first started } \\
\text { cooking (years) } \\
\geq 21 \\
7-20 \\
\text { Number of stir fryings per week } \\
0-4 \\
\geq 5 \\
\text { Number of fryings per week } \\
0-4 \\
\geq 5 \\
\text { Number of deep fryings per week } \\
0-4 \\
\geq 5 \\
\text { Use of fume extractor for } \\
\text { duration of } 20-40 \text { years } \\
\text { Yes } \\
\text { No }\end{array}$ & $\begin{array}{l}1.0(-) \\
1.6(0.8-3.0) \\
1.0(-) \\
2.4(1.1-5.2) \\
1.0(-) \\
2.3(1.2-4.6) \\
1.0(-) \\
0.9(0.5-1.9)\end{array}$ & $\begin{array}{l}\text { Age-matched analyses } \\
\text { adjusted for socioeco- } \\
\text { nomic status, residen- } \\
\text { tial area, and educa- } \\
\text { tion; study population } \\
\text { and exposure indices } \\
\text { clearly defined; all } \\
\text { diagnoses con- } \\
\text { firmed histologically }\end{array}$ \\
\hline
\end{tabular}


Table 1. Continued

\begin{tabular}{|c|c|c|c|c|}
\hline Study period & Study population & Comparison & Odds ratio ( $95 \%$ confidence interval) & Comments \\
\hline $\begin{array}{l}1983-1984 ; \\
\text { Liu et al, } 1993 \\
(13)\end{array}$ & $\begin{array}{l}224 \text { male and } 92 \text { female } \\
\text { case subjects; } 224 \text { male } \\
\text { and } 92 \text { female hospital } \\
\text { patients in Guanzhou, } \\
\text { China; case subjects and } \\
\text { referents matched for } \\
\text { age, gender, residential } \\
\text { district, and date of } \\
\text { diagnosis or hospital } \\
\text { admission; patients with } \\
\text { chronic respiratory } \\
\text { diseases or cancer } \\
\text { excluded from reference } \\
\text { group; nonresponse } \\
\text { rate: } 3 \% \text { for the case } \\
\text { subjects and } 0 \% \text { for the } \\
\text { referents; } 32 \% \text { of the } \\
\text { diagnoses confirmed } \\
\text { histologically }\end{array}$ & $\begin{array}{l}\text { Number of meals prepared at } \\
\text { home per day } \\
0-1 \\
2 \\
3 \\
\text { Separate kitchen } \\
\text { Yes } \\
\text { No } \\
\text { "Good" air circulation } \\
\text { Yes } \\
\text { No } \\
\text { Area of ventilation opening } \\
\text { in kitchen (m²) } \\
0.0-0.4 \\
0.5-0.9 \\
1.0-1.4 \\
1.5-1.9 \\
\geq 2.0 \\
\text { Test for linear trend: men } P<0.001 \text {, } \\
\text { women } P<0.001\end{array}$ & $\begin{array}{l}\text { Men: } 1.0(-) \text {; women: } 1.0(-) \\
\text { Men: } 0.8(0.3-2.6) \text {; women: } 0.5(0.03-8.8) \\
\text { Men: } 1.3(0.5-3.3) \text {; women: } 1.5(0.1-17.7) \\
\text { Men: } 1.0(-) \text {; women: } 1.0(-) \\
\text { Men: } 2.4(1.4-4.2) \text {; women: } 5.9(2.1-16.0) \\
\text { Men: } 1.0(-) \text {; women: } 1.0(-) \\
\text { Men: } 2.1(1.2-3.8) ; \text { women: } 3.6(1.4-9.3)\end{array}$ & $\begin{array}{l}\text { Matched analyses, } \\
\text { adjusted for smoking, } \\
\text { passive smoking, } \\
\text { education, occupation, } \\
\text { living area, and family } \\
\text { history of lung cancer, } \\
\text { chronic bronchitis, } \\
\text { and tuberculosis; } \\
\text { estimates of relative } \\
\text { risk imprecise; the } \\
\text { patterns of risk } \\
\text { between the men and } \\
\text { the women differed } \\
\text { dramatically for some } \\
\text { indices }\end{array}$ \\
\hline $\begin{array}{l}1985-1987 \\
\text { Wu-Williams } \\
\text { et al, } 1990(14)\end{array}$ & $\begin{array}{l}964 \text { female case subjects } \\
\text { and } 959^{b} \text { women selected } \\
\text { from the general } \\
\text { population in Shenyang, } \\
\text { Harbin, China; } \\
\text { nonresponse rate: } 8.0 \% \\
\text { for the case subjects and } \\
0 \% \text { for the referents; } 42 \% \\
\text { of diagnoses confirmed } \\
\text { histologically }\end{array}$ & $\begin{array}{l}\text { Number of years using coal stoves } \\
\quad 0-20 \\
21-40 \\
\geq 41 \\
\text { Deep-frying (times per month) } \\
0 \\
1 \\
1 \\
2 \\
\text { Eye irritation } \\
\text { Never or rarely } \\
\text { Sometimes } \\
\text { Frequently }\end{array}$ & $\begin{array}{l}1.0(-) \\
1.2(1.0-1.6) \\
1.2(1.0-1.7) \\
1.0(-) \\
1.2(1.0-1.5) \\
2.1(1.5-2.8) \\
1.9(1.4-2.7) \\
1.0(-) \\
1.6(1.2-1.8) \\
1.7(1.3-2.6)\end{array}$ & $\begin{array}{l}\text { Adjusted for age, } \\
\text { education, smoking, } \\
\text { and study area; study } \\
\text { population and } \\
\text { exposure indices } \\
\text { defined clearly; low } \\
\text { proportion of cases } \\
\text { confirmed } \\
\text { histologically }\end{array}$ \\
\hline $\begin{array}{l}1985-1987 \\
\text { Xu et al, } 1989 \\
(15)\end{array}$ & $\begin{array}{l}729 \text { male and } 520 \text { female } \\
\text { case subjects and } 788 \\
\text { men and } 557 \text { women } \\
\text { selected from the general } \\
\text { population in Shenyang, } \\
\text { China; nonresponse rate: } \\
5.0 \% \text { for the case } \\
\text { subjects and } 0 \% \text { for the } \\
\text { referents; about } 78 \% \text { of } \\
\text { the diagnoses confirmed } \\
\text { histologically }\end{array}$ & $\begin{array}{l}\text { Number of years cooking } \\
\text { in bedroom } \\
\quad 1-29 \\
\quad \geq 30 \\
\text { Test for linear trend: men } P<0.05 \text {, } \\
\text { women } P<0.05\end{array}$ & $\begin{array}{l}\text { Men: } 1.0 \text {; women: } 1.0 \\
\text { Men: } 1.2^{c} ; \text { women: } 1.5^{\circ} \\
\text { Men: } 2.1^{c} ; \text { women: } 1.8^{c}\end{array}$ & $\begin{array}{l}\text { Adjusted for age, } \\
\text { education, and } \\
\text { smoking; study } \\
\text { population and } \\
\text { exposure indices } \\
\text { defined clearly }\end{array}$ \\
\hline $\begin{array}{l}1984-1986 \\
\text { Gao et al, } 1987 \\
(18)\end{array}$ & $\begin{array}{l}672 \text { female case subjects } \\
\text { and } 635 \text { referents } \\
\text { frequency-matched for } \\
\text { age and selected from } \\
\text { the general population } \\
\text { of Shanghai, China; non- } \\
\text { response rate } 12.0 \% \text { for } \\
\text { the subjects and } 9.7 \% \\
\text { for the referents; } 43 \% \text { of } \\
\text { the diagnoses confirmed } \\
\text { histologically }\end{array}$ & $\begin{array}{l}\text { Using rapeseed versus soybean oil } \\
\text { Eye irritation (EI) and house } \\
\text { smokiness (HS) } \\
\text { No El and no HS } \\
\text { No El and somewhat or } \\
\text { considerable HS } \\
\text { Sometimes or frequently } \\
\text { El and no HS } \\
\text { Frequent El and } \\
\text { somewhat or considerable } \\
\text { HS } \\
\text { Number of dishes by stir-frying } \\
\text { per week } \\
<20 \\
20-24 \\
25-29 \\
\geq 30 \\
\text { Number of dishes by deep-frying } \\
\text { per week } \\
0 \\
1 \\
2 \\
\geq 3\end{array}$ & $\begin{array}{l}2.6(1.8-3.7) \\
1.0(-) \\
1.2(0.9-1.5) \\
1.2(0.8-1.9) \\
2.6(1.3-5.0) \\
1.0(-) \\
1.5(1.0-2.1) \\
1.6(0.8-3.2) \\
1.9(0.5-6.8)\end{array}$ & $\begin{array}{l}\text { Adjusted for age, } \\
\text { education, and } \\
\text { smoking; study } \\
\text { population and } \\
\text { exposure indices } \\
\text { defined clearly; low } \\
\text { proportion of cases } \\
\text { confirmed } \\
\text { histologically }\end{array}$ \\
\hline
\end{tabular}


Table 1. Continued

\begin{tabular}{|c|c|c|c|c|}
\hline Study period & Study population & Comparison & Odds ratio (95\% confidence interval) & Comments \\
\hline $\begin{array}{l}1985-1986 \\
\text { Liu et al, } 1991 \\
(19)\end{array}$ & $\begin{array}{l}56 \text { male and } 54 \text { female } \\
\text { case subjects and } 224 \\
\text { male and } 202 \text { female } \\
\text { subjects selected from } \\
\text { the general population of } \\
\text { Xuanwei, China; case } \\
\text { subjects and referents } \\
\text { matched for age, gender, } \\
\text { and village of residency; } \\
\text { nonresponse rate: } 0 \% \text { for } \\
\text { the case subjects and } \\
5.8 \% \text { for the referents; } \\
17 \% \text { of the diagnoses } \\
\text { confirmed histologically }\end{array}$ & $\begin{array}{l}\text { Often cooking food (yes versus no) } \\
\text { Age of started cooking } \\
>15 \\
\quad 11-15 \\
\leq 10 \\
\text { Number of years of cooking } \\
\quad \leq 30 \\
\quad 31-44 \\
\geq 45\end{array}$ & $\begin{array}{l}\text { Men: } 3.4(1.3-8.9) \\
\text { Women: } 1.0(-) \\
\text { Women: } 2.4(1.1-5.2) \\
\text { Women: } 1.0(0.5-3.5) \\
\text { Women: } 1.0(-) \\
\text { Women: } 9.2(1.8-47.5) \\
\text { Women: } 14.7(1.6-134.0)\end{array}$ & $\begin{array}{l}\text { Matched analyses, } \\
\text { adjusted for smoking, } \\
\text { passive smoking, and } \\
\text { family history of lung } \\
\text { cancer; exposure } \\
\text { indices not well } \\
\text { defined; imprecise } \\
\text { estimates of relative } \\
\text { risk for the women }\end{array}$ \\
\hline $\begin{array}{l}\text { Not given; } \\
\text { Wang et al, } \\
1992(20)\end{array}$ & $\begin{array}{l}154 \text { female case subjects } \\
\text { and } 154 \text { women selected } \\
\text { from neighborhoods of } \\
\text { the case subjects in } \\
\text { Nanjing, China; case } \\
\text { subjects and referents } \\
\text { matched for age, gender, } \\
\text { and residential district }\end{array}$ & $\begin{array}{l}\text { Smokiness during cooking versus } \\
\text { no smokiness } \\
\text { Using nongaseous fuel versus } \\
\text { gaseous fuel }\end{array}$ & $\begin{array}{l}\text { Squamous cell cancer: } 3.8(1 . \dagger-13.7) \\
\text { adenocarcinoma } 3.5(1.2-9.6) \\
\text { Squamous cell cancer } 5.0(0.8-30.9)\end{array}$ & $\begin{array}{l}\text { Matched analyses, and } \\
\text { adjusted for smoking, } \\
\text { and family history of } \\
\text { cancer; all diagnoses } \\
\text { confirmed histological- } \\
\text { ly; exposure indices } \\
\text { not well defined; } \\
\text { response rates not } \\
\text { specified }\end{array}$ \\
\hline $\begin{array}{l}\text { 1992-1994; } \\
\text { Zhong et al, } \\
\text { in press (21) }\end{array}$ & $\begin{array}{l}504 \text { nonsmoking female } \\
\text { case subjects and } 601 \\
\text { nonsmoking female } \\
\text { referents selected } \\
\text { randomly from the } \\
\text { general population in } \\
\text { Shanghai, China; cases } \\
\text { and referents frequency- } \\
\text { matched for age; } 77 \% \text { of } \\
\text { the case subjects } \\
\text { histologically confirmed; } \\
\text { nonresponse rate: } 8 \% \\
\text { for the case subjects } \\
\text { and } 0 \% \text { for the referents }\end{array}$ & $\begin{array}{l}\text { Cooking in a separate kitchen } \\
\text { Yes } \\
\text { No } \\
\text { Area of windows in the apartment } \\
\text { of longest residency } \\
<1.2 \\
1.2-1.8 \\
1.9-2.5 \\
2.6-3.8 \\
3.9-5.0 \\
5.1-8.0 \\
>8.0 \\
\text { Cooking at high temperature } \\
\text { No } \\
\text { Yes } \\
\text { Smokiness in the kitchen during } \\
\text { cooking } \\
\text { None or slight } \\
\text { Somewhat } \\
\text { Considerable } \\
\text { Eye irritation during cooking } \\
\text { Never } \\
\text { Rarely } \\
\text { Sometimes } \\
\text { Frequently } \\
\text { Most often used oil } \\
\text { Soybean oil } \\
\text { Rapeseed oil } \\
\text { Both oils } \\
\text { Number of stir-fryings per week } \\
<7 \\
7 \\
>7 \\
\text { Number of fryings per week } \\
\leq 1 \\
>1 \\
\text { Number of deep-fryings per week } \\
\leq 1 \\
>1 \\
\text { (n) }\end{array}$ & $\begin{array}{l}1.0 \\
1.3(1.0-1.7) \\
1.0 \\
1.0(0.6-1.5) \\
1.0(0.6-1.5) \\
1.0(0.6-1.6) \\
0.5(0.3-1.9) \\
0.9(0.5-1.6) \\
0.8(0.3-1.9) \\
1.0 \\
1.6(1.2-2.2) \\
1.0 \\
1.7(1.3-2.2) \\
2.4(1.6-3.6) \\
1.0 \\
1.5(0.9-2.4) \\
1.8(1.2-2.6) \\
1.7(1.0-2.8) \\
1.0 \\
1.8(1.1-3.0) \\
0.9(0.4-2.3) \\
1.0 \\
0.4(0.2-0.8) \\
2.3(0.7-8.0) \\
1.0 \\
2.1(1.1-3.8) \\
1.0 \\
1.9(1.1-3.3)\end{array}$ & $\begin{array}{l}\text { Adjusted for age, } \\
\text { education, income, } \\
\text { intake of vitamin C, } \\
\text { passive smoking, } \\
\text { family history of lung } \\
\text { cancer, and occupa- } \\
\text { tion; study population } \\
\text { and exposure indices } \\
\text { defined clearly }\end{array}$ \\
\hline
\end{tabular}

a The $95 \%$ confidence intervals were calculated by us from the published data.

${ }^{b}$ Including 520 female case subjects and 557 female referents in the study by $X u$ et al (15).

- The $5 \%$ confidence intervals were not provided in the original paper.

and reference groups were no more than $8 \%$. The proportion of diagnoses confirmed histologically varied from $17 \%(19)$ to $100 \%(6,20)$, with 1 study not providing details (3). In 4 studies, the case subjects were individually matched to referents by age, gender, and other factors $(6,13,19,20)$, and in the remaining 5 studies the case and referent subjects were frequency-matched by age and gender $(3,14,15,18,21)$. Although 
nonsmoking subjects were included in only 2 studies ( 6 , 21 ), smoking and other important risk factors, such as age, were taken into account in the analyses of all but 1 study (3). In only 1 study were dietary factors accounted for $(21)$

\section{Assessment of exposure to indoor air pollution from Chinese-style cooking}

Traditionally, Chinese women cook with rapeseed or soybean oil. About $25-100 \mathrm{ml}$ of cooking oil is placed in a wok and then heated to approximately $260-280^{\circ} \mathrm{C}$. Chinese-style cooking methods can be classified as 3 types, depending on the amount of oil used, the cooking temperature, and the duration of cooking time: stir-frying, frying, and deep-frying. High cooking temperatures can result in the generation of a large amount of smoke from the oil, and these fumes can irritate eyes and mucous membranes. All of the studies used structured questionnaires administered through face-to-face interviews with subjects to capture different features of exposure: use of Chinese-style cooking, ventilation conditions (eg, area of windows, installation of fume extractors, having a separate kitchen), type of cooking oil used, smokiness of the home, eye irritation during cooking, and number of meals prepared by stir-frying, frying, and deep frying techniques.

After considering the design characteristics and the assessment of exposure in the individual studies, we are of the opinion that the population-based case-referent studies by Gao et al (18), Wu-Williams et al (14), Xu et al (15), and Zhong et al (21) and the hospital-based casereferent study by Ko et al (6) were the strongest studies because the study populations and exposure indices were well defined and potential confounding was adequately controlled. These 6 studies provided relatively stable estimates of the association between the risk of lung cancer and indoor air pollution from Chinese-style cooking. The remaining studies were less informative either because exposure indices were not defined clearly $(3,20)$ or the estimates of relative risk were imprecise (low statistical power $)(13,19)$.

\section{Quantitative associations between lung cancer and factors related to Chinese-style cooking}

The first study (3) reporting the association was carried out in Singapore between 1972 and 1973 and included only Chinese residents. Exposure to Chinese-style cooking was defined as whether subjects ever cooked using Chinese-style methods. It was found that Chinese men who cooked had a 1.6-fold increased risk of lung cancer [95\% confidence interval ( $95 \%$ CI) $0.7-3.2]$. In addition, Cantonese women had a $70 \%$ excess risk [odds ratio (OR) $1.7,95 \%$ CI $0.7-4.5$ ], but a decreased risk was found among non-Cantonese women (OR 0.4, 95\% CI $0.2-0.9$ ). The investigators proposed that the different patterns between Cantonese and non-Cantonese women in the risk of lung cancer could be due to the Cantonese using stir-frying more frequently than non-Cantonese. A 3.4-fold (95\% CI 1.3-8.9) increased risk of lung cancer was reported for men who often cooked (19). The authors also found that women who started to cook between 11 and 15 years of age were at higher risk (OR 2.4, 95\% CI 1.1-5.2) than women who started to cook when they were older. Another study found that women who started cooking before the age of 21 years had a $60 \%$ excess risk (OR 1.6, 95\% CI 0.8-3.0) when compared with women who started cooking at older ages (6).

The associations between the risk of lung cancer and the frequency of stir-frying, frying, or deep-frying were analyzed in 4 studies $(6,14,18,21)$. These studies revealed that there was a consistent excess risk of lung cancer among subjects who more frequently used these methods. Ko et al (6) reported an odds ratio of 2.4 (95\% CI $1.1-5.2)$ for subjects who stir-fried meals more than 4 times a week as compared with subjects who did not use this method as often. Similar estimates of risk were found in other studies for deep-frying $(6,14,21)$ and frying $(14$, 18,21 ). Odds ratios varying from 1.7 to 3.5 were reported for frequent eye irritation $(14,18,21)$ and for considerable smokiness in the home during cooking $(18,20$, 21 ). Women who most frequently used rapeseed oil to cook experienced increased odds ratios for lung cancer that ranged from $1.4(95 \% \mathrm{CI} 1.1-1.8)(18)$ to $1.8(95 \%$ CI $1.1-3.0)(21)$.

The extent of ventilation is another factor that has been found to be associated with the risk of lung cancer. $\mathrm{Xu}$ et al (15) found that women who cooked in the bedroom for more than 30 years were at a $80 \%$ excess risk of developing lung cancer compared with women cooking in a separate kitchen; for men, the odds ratio was 2.1 . For not having a separate kitchen, Liu et al (13) reported odds ratios of $5.9(95 \%$ CI $2.1-16.0)$ for women and $2.4(95 \% \mathrm{CI} 1.4-4.2)$ for men. Zhong et al (21) found lower excess risks (OR 1.3, 95\% CI 1.0-1.7) among nonsmoking women who did not have separate kitchens, An odds ratio of 8.3 was found for women who cooked meals in kitchens not equipped with fume extractors (95\% CI 3.1 - 22.7) (6). Inconsistent findings have been reported in 2 studies $(13,21)$ that used the total area of the windows in subjects' apartments as a surrogate measure for ventilation.

\section{Estimates of the etiologic fraction}

We calculated the etiologic fraction for each study in which estimates of relative risks for certain well-defined indices of exposure were provided. The calculation made use of the proportion of subjects exposed in the 
Table 2. Summary estimates of etiologic fractions (percent) for selected indices of exposure to Chinese-style cooking.

\begin{tabular}{lc}
\hline Exposure index & Etiologic fraction (\%) \\
\hline Not having a separate kitchen & \\
Liu, 1993 (13) & 68 \\
$\quad$ Men & 41 \\
$\quad$ Women & 6 \\
Xu, 1989 (15) & 10 \\
Zhong, in press (21) & \\
Cooking at high temperature & 14 \\
$\quad$ Zhong, in press (21) & \\
Smokiness in the home during cooking & 26 \\
Gao, 1987 (18) & 30 \\
Zhong, in press (21) & \\
Eye irritation & 12 \\
Zhong, in press (21) & \\
Most often cooked with rapeseed oil & 16 \\
Gao, 1987 (18) & 4 \\
Zhong, in press (21) & \\
Frying more than once a week & 4 \\
Zhong, in press (21) & \\
Deep-frying more than once a week & 62 \\
Wu-Williams, 1990 (14) & 3 \\
Gao, 1987 (18) & \\
Zhong, in press (21) & 67 \\
Not using a fume extractor & \\
Ko, 1997 (6) & \\
\hline
\end{tabular}

reference series and estimates of relative risk for each exposure group (27). The calculations were carried out for not having a separate kitchen, cooking at high temperature, smokiness in the home during cooking, eye irritation, most often using rapeseed oil, frying more than once a week, deep-frying more than once a week, and not using fume extractors (table 2). As there are few independent estimates available for each index and considerable variability in the estimates exists, it is difficult to derive a summary value. This variability in the etiologic fractions was likely due to sampling error, slightly different definitions of the indices, and different prevalence rates of exposure in the study populations.

\section{Discussion}

Our review suggests that the risk of lung cancer is increased in both Chinese women and men who are exposed to indoor air pollutants from Chinese-style cooking. Although the epidemiologic studies were conducted in different parts of China and Singapore, the results are fairly consistent. Moreover, experimental studies showed that volatile emissions from oils heated in woks are mutagenic in several in vitro short-term test systems $(22,23)$. Several toxic agents, including some accepted and suspected carcinogens, were detected in the emissions of the heated cooking oils $(23,24)$.
The magnitude of the association may have been underestimated in these studies because of errors in the measurement of exposure and in the diagnosis of lung cancer. With regard to misclassification of exposure, a variety of indices was used as a surrogate to estimate exposure to indoor air pollution arising from heated cooking oils. These indices were developed from interviews that were based on structured questionnaires. To the best of our knowledge, the validity and reliability of these instruments have not been evaluated. The degree to which these questionnaire-based indices approximate actual levels of exposure should, to a large extent, depend on subjects' ability to recall cooking conditions. It seems plausible that recall was reasonably accurate, as methods of cooking do not appear to change through time, although different oils are used (depending on price and availability). It must also be emphasized that, when these studies were conducted, neither the subjects nor the interviewers were aware of the potential association between exposure to volatile emissions from heated cooking oils and the risk of lung cancer. It would therefore appear that the misclassification of exposure was nondifferential and that the estimated associations were attenuated (28).

An additional source of measurement error would be expected to occur when surrogate subjects were the respondents. However, in the only study in which these effects were investigated (21), it was found that the results from the analyses restricted to self-respondents were generally similar to those for all subjects.

Misclassification of the diagnoses of lung cancer was likely to have occurred in the 4 studies in which more than $50 \%$ of the cases were diagnosed solely on clinical or radiological evidence or both $(13,14,18,19)$. Although this misclassification was probably independent of exposure, and thus should have attenuated the associations (28), the results from these studies $(14,18)$ were similar to those from the studies in which at least $75 \%$ of the cases were confirmed histologically $(6,21)$. In our own study (21) we found that the analyses restricted to histologically or cytologically confirmed cases gave virtually identical results to those obtained when all cases of lung cancer were included. These results therefore suggest that the errors in the misclassification of diagnoses of lung cancer were minor.

Two studies $(6,21)$ were conducted among nonsmoking subjects while all the other studies $(3,13-15,18$ 20) controlled for active smoking in the data analysis stage. Although passive smoking was controlled for in only 3 studies $(13,19,21)$, it is likely that it would not strongly distort the association between lung cancer and cooking because of its weak association with lung cancer (35). On the other hand, the associations may have been overestimated because of the lack of control for diet. Several investigations have shown consistent associations 
between some aspects of diet (eg, low consumption of vegetable and fruits) and lung cancer (29-32). Nutritional studies have shown that the activity of vitamin $\mathrm{C}$ (33) and beta-carotene (34) is reduced when foods are cooked at high temperatures, and thus subjects who usually prepared meals at higher temperatures tended to have a lower intake of vitamin $\mathrm{C}$ and beta-carotene, which might have resulted in higher risks of lung cancer. In the only study in which diet was accounted for (21), changes in the estimates of relative risk were minimal after control for diet; this finding suggested, contrary to the precedng arguments, that diet may not have played an important role in these studies.

All of the epidemiologic studies reviewed were casereferent investigations, which may be subject to more sources of bias than cohort studies. The most serious potential problem in case-referent studies is that the procedures used to select cases and referents may produce groups that are not truly comparable. In 3 studies (3, 6, 13), both lung cancer cases and referents were enrolled from hospitals and the investigators of these studies reported that the hospitals had almost complete coverage of the study populations. The types of diseases that referents had varied between the studies, but referents with smoking-related diseases or tumors were excluded. In both hospital-based and population-based case-referent studies, the response rates were very high. More importantly, the results for the population-based $(14,18,21)$ and the hospital-based (6) studies were similar. These data suggest that the case subjects and referents were probably representative of the target populations from which the cases arose. In other words, selection bias is an unlikely explanation for the associations.

In conclusion, the evidence from epidemiologic investigations, although limited, suggests that the risk of lung cancer in Chinese populations may be associated with indoor air pollution from Chinese-style cooking. The association is unlikely due to chance, misclassification error, or selection bias. In addition, one cannot exclude the possibility that the associations may have been overestimated because of inadequate control for confounding. Further research, such as long-term animal studies, are needed to understand further the magnitude of the risks involved, as well as providing ancillary data regarding mechanisms. When designing and conducting further epidemiologic studies, researchers should take into account all key potential confounding factors.

Because Chinese-style cooking is used widely and frequently by the Chinese, the risk of lung cancer from exposure to indoor air pollution from Chinese-style cooking does not have to be very large to lead to an important public health hazard. It is thus prudent to suggest the implementation of control measures to reduce exposure, such as increasing ventilation in the kitchen, installing fume extractors, and cooking at lower temperatures.

\section{Acknowledgments}

The authors are grateful to Dr Jean-François Boivin for his insightful comments and suggestions. We also want to thank Dr Yong-Hua Qu and Yiong-Bin Xiang for their help in identifying papers published in Chinese and Ms Holly Lam for her assistance with the literature search.

Dr Goldberg gratefully acknowledges the receipt of a national health scholar award from the National Health and Research Development Program of Health Canada and also support from the Fonds de la recherche en santé du Québec.

\section{References}

1. Jin F, Devesa SS, Zheng W, Blot WJ, Fraumeni JF Jr, Gao Y$\mathrm{T}$, et al. Cancer incidence trends in urban Shanghai, 19721989. Int J Cancer 1993;53:764-70.

2. Muir C, Waterhouse J, Mack T, Powell J, Whelan S, editors. Cancer incidence in five continents; vol V. Lyon: International Agency for Research on Cancer (IARC), 1986. IARC scientific publication, no 88 .

3. MacLennan M, Coates MS, Day NE, Law CH, Ng YK, Shanmugaratnam K. Risk factors for lung cancer in Singapore Chinese, a population with high female incidence rates. Int J Cancer 1977;20:854-60.

4. Koo LC, Ho JH Lee PN. An analysis of some risk factors for lung cancer in Hong Kong. Int J Cancer 1985;35:149-55.

5. Koo LC, Ho JH, Saw D, Ho CY. Measurements of passive smoking and estimates of lung cancer risk among nonsmoking Chinese females. Int J Cancer 1987;39:162—9.

6. Ko YC, Lee CH, Chen MJ, Huang CC, Chang WY, Lin HJ, et al. Risk factors for primary lung cancer among nonsmoking women in Taiwan. Int J Epidemiol 1997;26:24-31.

7. Hinds MW, Kolonel LN, Hankin JH, Lee J. Dietary vitamin A, carotene, vitamin C and risk of lung cancer in Hawaii. Am J Epidemiol 1984;119:227-37.

8. Green JP, Brophy P. Carcinoma of lung in nonsmoking Chinese women. West J Med 1982;136:291-4.

9. Fraumeni JF Jr, Mason TJ. Cancer mortality among Chinese Americans, 1950-69. JNCI 1974;52:659-65.

10. McCredie M, Coates MS. Cancer incidence in migrants to New South Wales, 1972 to 1984: NSW Central Cancer Registry. Sydney: NSW Cancer Council, 1989.

11. Menon MA, Saw HS. Lung cancer in Malaysia. Thorax 1979;34:269-73.

12. Deng J, Gao YT. Prevalence of smoking among 110,000 adult residents in Shanghai urban area. Chinese J Prev Med $1985 ; 19: 271-4$.

13. Liu Q, Sasco AJ, Riboli E, Hu MX. Indoor air pollution and lung cancer in Guanzhou, People's Republic of China. Am J Epidemiol 1993;137:145-54.

14. Wu-Williams AH, Dai XD, Blot WJ, Xu ZY, Sun XW, Xiao $\mathrm{HP}$, et al. Lung cancer among women in northeast China. $\mathrm{Br} \mathbf{J}$ Cancer 1990;62:982-7.

15. Xu ZY, Blot WJ, Xiao HP, Wu A, Feng YP, Stone BJ, et al. Smoking, air pollution, and the high rates of lung cancer in Shenyang, China. JNCI 1989;81:1800-6.

16. Gao YT, Blot WI, Zheng W, Fraumeni JF Jr, Hsu C-W. Lung 
cancer and smoking in Shanghai. Int $\mathbf{J}$ Epidemiol $1988 ; 17: 277-80$.

17. Levin LI, Zheng W, Blot WJ, Gao Y-T, Fraumeni JF Jr. Occupation and lung cancer in Shanghai: a case-control study Br J Ind Med 1988;45:450-8.

18. Gao YT, Blot WJ, Zheng W, Ershow AG, Hsu CW, Levin LI, et al. Lung cancer among Chinese women. Int J Cancer 1987;40:604-9.

19. Liu ZY, He XZ, Chapman RS. Smoking and other risk factors for lung cancer in Xuanwei, China. Int $J$ Epidemiol 1991;20:26-31.

20. Wang GX, Shen XB, Shen QJ, Xiang LS, Chao JW, Zhang LB, et al. Multivariate analyses of causal factors including cooking oil fumes and others in matched case-control study of lung cancer. Chinese J Prev Med 1992;26:89-91.

21. Zhong LJ, Goldberg MS, Gao, YT, Jin F. Lung cancer and indoor air pollution arising from Chinese-style cooking among nonsmoking women living in Shanghai, China. Epidemiology. In press.

22. Qu YH, Xu GX, Zhou JZ, Chen TD, Zhu LF, Shields PG, et al. Genotoxicity of heated cooking oil vapors. Mutat Res 1992;298:105-11.

23. Shields PG, Xu GX, Blot WJ, Fraumeni JF Fr, Trivers GE, Pellizzari ED, et al. Mutagens from heated Chinese and US cooking oils. JNCI 1995;87:836-41.

24. Pellizzari ED, Michael LC, Thomas KW, Shields PG, Harris C. Identification of 1,3 butadiene, benzene, and other volatile organics from wok oil emissions. J Exp Anal Environ Epidemiol 1995;5:77-87.

25. International Agency for Research on Cancer (IARC). Occupational exposures to mists and vapours from strong inorganic acids, and other industrial chemicals. Lyon: IARC, 1992:1-336. IARC monograph series, vol 54.

26. International Agency for Research on Cancer (IARC). Over- all evaluations of carcinogenicity: an updating of selected IARC monographs, vols 1-42. Lyon: IARC, 1987:6-24.

27. Kleinbaum DG, Kupper LL, Morgenstern H. Epidemiologic research: principles and quantitative methods. New York (NY): Van Nostrand Reinhold, 1982:159-82.

28. Copeland KT, Checkoway H, McMichael AT, Holbrook RH. Bias due to misclassification in the estimation of relative risk. Am J Epidemiol 1977;105:488—95.

29. Willett W. Vitamin A and lung cancer In: Nutritional epidemiology. New York (NY): Oxford University Press, 1990:292-310.

30. Samet JM, Skipper BJ, Humble CG, Pathak DR. Lung cancer risk and vitamin A consumption in New Mexico. Am Rev Respir Dis 1985;131:198-202.

31. Byers $T$. Diet as a factor in the etiology and prevention of lung cancer. In: Samet JM, editor. Epidemiology of lung cancer. New York (NY): Marcel Dekker Inc, 1994:335-52.

32. Colditz GA, Branch LG, Lipnick RJ, Willett WC, Rosner B, Posner B, et al. Increased green and yellow vegetable intake and lowered cancer deaths in an elderly population. Am J Clin Nutr 1985;41:32-6.

33. Hallberg L, Rossander L, Persson H, Svahan E. Deleterious effects of prolonged warming of meals on ascorbic acid content and iron absorption. Am J Clin Nutr 1982;36:846-50.

34. Borenstein B, Lachance PA. Effects of processing and preparation of the nutritive value of foods. In: Shils ME, Young VR, editors. Modern nutrition in health and disease. Philadelphia (PA): Lea \& Febiger, 1988:672-84.

35. Environmental Protection Agency (EPA). Respiratory health effects of passive smoking: lung cancer and other disorders. Washington (DC): US EPA, Office of Research and Development RD-689, 1992. EPA/6006-90/006F.

Received for publication: 3 December 1998

\section{APPENDIX}

Volatile organic compounds identified in fumes from heated Chinese rapeseed, soybean, peanut oil, and North American canola oil ${ }^{\text {a }}$

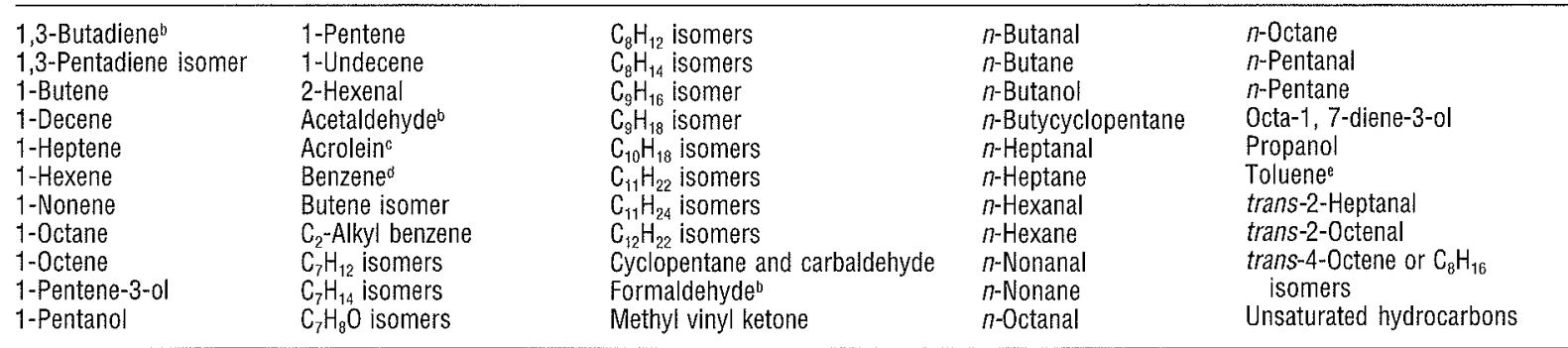

a Taken from references 23 and 24 of the body of the report.

b Probable human carcinogen, according to the International Agency for Research on Cancer in reference 25 of the body of the report.

- Mutagenic, according to the International Agency for Research on Cancer in reference 26 of the body of the report.

accepted human carcinogen, according to the International Agency for Research on Cancer in reference 25 of the body of the text.

e Genotoxic, according to the International Agency for Research on Cancer in reference 25 of the body of the text. 